\title{
INVENTING A NATIONAL WRITER: THE SOVIET CELEBRATION OF THE 1948 ALISHER NAVOI JUBILEE AND THE WRITING OF UZBEK HISTORY
}

\section{Boram Shin}

Asia-Pacific Research Center, Hanyang University
E-mail shboram@gmail.com

This article traces the process through which Alisher Navoi, a fifteenth-century ChagataiTurkic poet from Herat, Afghanistan, became uzbekified and sovietized by Uzbek writers and scholars from the I920s to the I940S. It focuses on how shifting visions of nation-building affected Navois representation in Uzbek national historiography during the early Soviet period. The I948 Soviet celebration of the 50oth anniversary of Alisher Navoi's birth established the poet as a symbol of Uzbek "national-exceptionalism" that distinguished the Uzbek nation from other Central Asian nations. As a consequence Alisher Navoi's legacies that had regional significance were reduced to national heritage and the region's history was revised accordingly. The article, however, argues that the Soviet canonization of Alisher Navoi was not a rootless imposition of cultural history unfamiliar to the Uzbek people. Rather it was a realization of a nation-building project initiated by native Central Asian intellectuals called Jadids before the very creation of the Uzbek nation-state. Even though these intellectuals were persecuted during the I930s Stalinist Terror, their ideas survived and were picked up by a new generation of Uzbek writers. This article also discusses how World War II provided an opportunity and justification for the Uzbek writers to rediscover their nation's pre-Revolutionary history and strengthened the Uzbek national ownership of Navoi legacies.

Keywords: Soviet national construction; Uzbek historiography; Alisher Navoi; World War II; literary canonization

\section{INTRODUCTION}

This article traces the historical process through which the fifteenth century Chagatai-Turkic poet Alisher Navoi (I44I-I5OI) was simultaneously uzbekified and sovietized from the I920s to the late I940s, and discusses how shifting visions and institutions of nation-building affected representations of Alisher Navoi as well as the cultural historiography of an Uzbek nation. Alisher Navoi remains perhaps the most celebrated literary figure in Uzbekistan. In 20I6, Uzbekistan established the State Uzbek Language and Literature University named after Alisher Navoi. The presidential decree that founded 
the new university outlines a brief history of the Uzbek language shaped by the "peoples and nations (elat va millatlar) that had inhabited the territory of our land [...]" and names key figures of Uzbek literature. It celebrates scholars from the eleventh century on whose heritage Uzbek literature was built and credits poets from later centuries for enhancing the elegance and beauty of Uzbek belles-lettres. Central Asian modernists or Jadid reformers from the turn of the twentieth century were commemorated as "true patriots" and "protectors" of the native language against colonial oppression. The greatest tribute, however, was paid to Alisher Navoi, who is the most representative figure of Uzbek literature and a national hero whose importance is equal to the great rulers Amir Timur, Babur, and Mirzo Ulugbek. President Karimov honored Alisher Navoi for "creat[ing], in our very own native language, the immortal works [that claim] their rightful place among the cultural treasures of humanity" and thus contributing immensely to the Timurid Renaissance when Uzbek literary language reached its peak of development. ${ }^{\mathrm{I}}$ Such celebration of Alisher Navoi is a reinstatement of earlier emphases on Navoi's status as an Uzbek national poet of international recognition. For example, in the 2004 edition of Latin-based Uzbek Alphabet and Orthography, which summarized post-independence language reforms and their implementations, only Alisher Navoi and his contributions were noted. He was described as a national hero who "fought for many years" to prove to the world the "artistic merit" of the Uzbek language, and thus "built the foundation for the Uzbek people to construct [their] own morals in [their] own native language.”2 It also stressed the importance of learning about Alisher Navoi's works and his legacies, which together served as a bridge between the Turkic literature that came before and after the poet.

To explain the historical significance of the establishment of the new Alisher Navoi University, the presidential decree links post-Soviet independence with national revival. According to the decree, the founding of the university marks the fulfilment of the Uzbek people's duty to preserve and further enrich their own language and literature, something which had become possible only after the I989 language reform. President Karimov also refers to the series of language policies adopted since I99I that made Uzbek the official language of the state, in order to emphasize that such legislative measures had not only reminded the people of their duty but also secured the people's rights to use and learn their native language and literature. Following the same logic, the Russian colonial and Soviet periods - when Jadid modernists had attempted to defend such rights are implicitly described as times of oppression. The president asserts: "It is no secret that during the oppressive period when we had fallen into the claws of subjugation, the possibility for our native language to develop was severely restricted."3 More balanced and elaborate yet similar views are reflected in how Uzbek scholars interpret the nation's Soviet past and cultural history/historiography written during the Soviet period. Revisiting Soviet historiography, Shoira Asadova notes that Uzbek cultural history written about the decades of the I920s to I940s closely followed the "ideological-political" scheme of Leninist progress and was premised on the preconceived notion that Uzbek culture was

I “Tarix,” Toshkent davlat o’zbek tili va adabiyoti universiteti, http://navoiy-uni.uz/uz-1/content/tarix [last accessed 25 January 20I7].

2 O`zbek Respublikasi Oliy va O`rta Maxsus Ta`lim Vazirligi 2004, p. 40. 
essentially "backward" and "underdeveloped". ${ }^{4}$ As a consequence, Soviet cultural history treated the "Leninist plan for socialist construction" or the "Soviet cultural revolution" that seemed inevitable and necessary for elevating Uzbek culture to the same level of development achieved by the Soviet centre that is Russia. Asadova argues that such an understanding of Soviet cultural and historical (interventionist) projects not only presented an "erroneous view of the reality" but also justified the "fact that the Russian language and Russian culture supplanted national components and eroded rich cultural and historical heritage, centuries-old traditions and customs of the Uzbek people”. ${ }^{5}$ Scholars approaching the question from a literary studies perspective share a similar opinion. They have argued that the imposition of Socialist Realism on local culture especially during the early decades of the Soviet period and ideology-driven, politicized literary criticism had ultimately limited explorations and appreciation of Uzbek literature to the fullest. ${ }^{6}$

For scholars observing post-Soviet nation(alism)-building from outside, however, Alisher Navoi is an often-cited case in point of an "invented nationalism" prevalent in today's Uzbekistan. From early on, Edward Allworth has raised the point that Alisher Navoi, who was born and died in Herat, Afghanistan, never identified himself as an Uzbek and, on the contrary, expressed harsh antagonism towards the nomadic Uzbek tribe. ${ }^{7}$ He argues that the poet represented a more general Turkic identity for the Central Asian modernists who first canonized him at the turn of the twentieth century. Quoting Allworth, Charles Kurzman notes, “Ironically, given Navoi's distaste for the Uzbeks of his day, his legacy is being corralled for [a] strain of nationalism-building: the

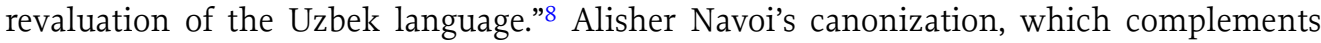
the state's efforts to push forward national language reforms, involves revision of the nation's history similar to that written during the Soviet era. Laura Adams's more recent study on post-Soviet cultural production and nation-building in Uzbekistan adds to Kurzman's observation, and notes that despite changes in content and messages contained in state-sponsored cultural products and activities, many Soviet cultural forms and institutions are in fact being recycled by today's regime. ${ }^{9}$

A number of studies have investigated the uses and abuses of the historical and cultural heritage associated with Alisher Navoi and the Timurid dynasty, but there are still issues that remain underexplored, including the actual historical processes and discourses involved. While the Soviet and post-Soviet states' mobilization of a revised, even distorted, history for the purpose of nation-building is emphasized, the questions of how and under what doctrines and conditions Soviet and Uzbek scholars and literary elites reconciled the ironies involving the poet's biography and constructed an "ideologically-correct" (or "not-so-correct" in this case) national history for a Soviet republic during the Stalinist

Asadova 20I4, pp. I93-94.

5 Ibid.

6 See Nazarov et al. 2012 (especially pp. 340-62, "Adabiy tanqidda tahlil va talqin muammolari," for an overview of Soviet and post-Soviet developments in local literary criticism); Mirzaeva 2015.

7 Allworth I964, pp. 37, 226-3I.

8 Kurzman I999, p. 86.

9 Adams 2010. 
decades of the I930s and I940s - the period when the Soviet tradition of massive celebrations of national writers began - have not been fully discussed. This article adds to the existing literature by further investigating the Soviet construction of "national exceptionalism" in uzbekifying while sovietizing Alisher Navoi in order to highlight the simultaneity and complementarity of the two seemingly-dichotomous processes. According to Sarah Corse, "National canonical status is ... rooted in national exceptionalism. Literary explorations of the 'unique' nation and its 'exceptional' experience in turn help construct available images of the nation." Io In the Soviet case, the idea of the "friendship of the Soviet peoples" founded on the principles of mutual trust and shared appreciation of all national cultures by and among all Soviet nations rendered national particularity more pronounced. In order to demonstrate this point, this article focuses on the I 948 all-Union commemoration of the 5ooth birthday of Alisher Navoi, which not only confirmed the poet's seat in the Soviet Olympus but also affirmed the Uzbek people's "national ownership" of the poet's and Timurid cultural heritage.

Before investigating the I930s and I940s Soviet commemoration of the Uzbek national poet, this article first revisits the early efforts of the Central Asian Jadids in order to explore the role of local Uzbek elites and to trace continuities and discontinuities in the visions and means of Uzbek nation-building. Perhaps ironically, the I948 Alisher Navoi Jubilee marked the realization of an earlier nation-building project initiated by Central Asian Jadids in the years preceding the establishment of the Uzbek SSR. Abdurauf Fitrat, the most renowned Jadid scholar from Bukhara, was one of the first and most ardent proponents of nationalization of the poet as part of his effort to establish a modern literature for a modern Central Asian nation. Although none of the Jadid initiators of the Navoi canonization survived the Stalinist Terror, their ideas influenced the Stalinist generation of local elites who came to prominence in the early I930s and were placed in charge of the Jubilee celebration. Also important was the idea of ethnogenesis proposed by the Russian orientalist Aleksandr Iakubovskii. Iakubovskii provided an "ideologically-correct" historiography of the Uzbek nation's pre-Revolutionary past that ultimately "amounted to selectively structuring the past in line with today's needs" at the dawn of a war when the spirit of Soviet patriotism based on the "friendship of the Soviet peoples" was most needed. ${ }^{\text {II }}$ Iakubovskii's thesis, which clearly located not only Alisher Navoi and Timurid cultural legacy but also that of previous eras within the Uzbek national history, will be discussed in the last section of this article, which deals with how the perception of the nation was affected by wartime exigencies during World War II.

The I930s and I940s Soviet canonization of the Chagatai-Turkic poet through a massive all-Union jubilee presents an especially interesting case, due not only to the many ironies associated with it but also to its timing. The Soviet celebration, whose preparation officially began in the mid-I930s when Stalinist cultural institutions were being implanted, was postponed by World War II, a major historical event that fundamentally affected every aspect of Soviet society. The last section of this article looks into how World War II, which interrupted and eventually postponed the Jubilee celebration, catalysed

\footnotetext{
Io Corse I997, p. 4.

II Ilkhamov 2004, p. 320.
} 
uzbekification of a Central Asian regional history, again revised by local writers and cultural elites faced with the task of promoting Soviet patriotism among the Uzbek population. The wartime exigencies that led to the decentralization of censorship allowed these elites to compromise ideological correctness and historical accuracy for the sake of unifying the Uzbek nation and rallying the local population behind the Soviet military cause. All such efforts helped the Uzbeks make a stronger claim for their exclusively national ownership of the poet Alisher Navoi.

\section{NATIONALIZING A POET: FROM NIZAM-AL-DIN ALI-SHIR HERAWI OF HERAT TO ALISHER NAVOI OF UZBEKISTAN}

Nizam-al-Din Ali-Shir Herawi, more commonly known as Alisher Navoi, was born in I44I (I426 according to the lunar calendar) in Herat, the city that became the cultural center of the late Timurid Empire. A bitter struggle for succession following the death of Timur, the empire's founder, continued during Navoi's lifetime, fragmenting and destabilizing the empire. Navoi served as the highest vizier (minister) at the court of Sultan Husayn Bayqara, his foster brother and the ruler of Khurasan with its capital in Herat, and brought relative stability and prosperity to the city's inhabitants. ${ }^{\mathrm{I}}$ Navoi was also a supporter of learning who founded the Ikhlasiyya complex where scholars, students, and artists gathered to enjoy his patronage. ${ }^{\text {I }}$ The most important legacy, which made Navoi the founder of Uzbek literature during the Soviet era, however, was his ardent advocacy of the literary merit of the Chagatai-Turkic language. Alisher Navoi, who was bilingual in Turkic and Persian, was more prolific in the Chagatai-Turkic language than in the Persian language. ${ }^{14}$ Babur praised the poet in his memoir, Baburnama: "Ali-shir Beg had no match. For as long as verse has been written in the Turki tongue, no-one has written so much or so well as he." ${ }^{5}$ Alisher Navoi challenged the convention of reckoning Persian as the only language suitable for literary composition while treating Chagatai-Turkic as a language of the military and peasantry. In Trials of the Two Languages (Muhakamat al-Lughatayn), the poet demonstrated the richness and malleability of the Chagatai lexicon to prove the superiority of the Chagatai language over the Persian language. Navoi also reworked some of the most celebrated masterpieces and traditional themes of Iranian and Arabic literature in Chagatai-Turkic to demonstrate the poetic beauty of the Chagatai-Turkic language. His most renowned work, Hamsa or collection of verses, included Farhad and Shirin (Farhod va Shirin) and Layli and Majnun (Layli va Majnun), both brilliant reworkings of the famous Persian and Arabic epic themes of Khosrow and Shirin and Layla and Majnun respectively. ${ }^{16}$

I2 Grousset I970, pp. 464-66.

I3 Subtelny I988, p. 49I.

I4 Alisher Navoi also wrote poetry in Persian. For verses written in Persian, the poet used the pen-name "Fani", which meant 'transitory' (Babur [trans. Beveridge] I922, p. 272).

I6 Alisher Navoi's Hamza consists of five divans or narrative poems: Wonders of Good People (Hayrat-al-abrar), Farhad and Shirin (Farhad va Shirin), Layli and Majnun (Layli va Majnun), Seven Planets (Sab'ai Sayyar), and Alexander's Dome (Sadd-i-Iskandar). 
Svatopluk Soucek has commented that "[Navoi's poetry] played a catalytic role in crystallisation of Turkic as a major literary language, and ... as proof that Turkic high culture too had come of age and could safely take its place beside Persian." ${ }^{77}$ It is precisely the fact that Alisher Navoi attempted to establish the Chagatai-Turkic language as a language of the arts against the intellectual conventions of the time which proved crucial for later generations of Central Asian scholars who venerated the poet as a national poet. ${ }^{\mathrm{I} 8}$

Alisher Navoi's poetry also provided cultural coherence across Central Asia. When describing his hometown of Andijan, Babur wrote: "Andijans are all Turks, not a man in town or bazzar but knows Turkic. The speech of the people is correct for the pen; hence the writings of Mir "Ali-shir Nawai, though he was bred and grew up in Hiri (Harat), are one with their dialect." ${ }^{9}$ As Fredrick Starr has also remarked, "The fact that [Alisher Navoi] wrote in a variety of poetic modes and genres, and that the language of nearly all his works was accessible to audiences beyond the palace grounds, assured his central place in the history of Turkic letters and his status as the national poet of the Uzbeks." ${ }^{20}$ The poet, however, could never himself foresee that he would represent "Uzbeks". According to Edward Allworth, Timurid authors, including Alisher Navoi, "contrasted themselves to Uzbeks, usually in unequivocal, sometimes unflattering terms." ${ }^{2 \text { I }}$ In Navoi's Alexander's Wall (Sadd-i Iskandariy), for example, Uzbeks were portrayed as siding with Alexander the Great's contenders and thus were associated with forces of evil..2 Furthermore, there existed a linguistic distinction between Alisher Navoi's Chagatai-Turkic language and the Turkic dialect spoken by the Uzbek tribes at the time. According to Allworth, the Qiqchak dialect spoken by the plain Uzbeks further differentiated them from Oghuz-influenced people in Khwarzm and the Turki-speaking people of Fergana Valley and eastern Turkistan that made up the Timurid Empire. ${ }^{23}$ Therefore, as Allworth has criticized, officially renaming Chagatai "Old Uzbek" and Chagatai literature "Uzbek" literature could indeed "badly distort the literary history of the region".24 Then, one may ask, if Alisher Navoi had clearly distinguished the Timurid and Chagatai Turks from Uzbeks, then on what grounds did the poet come to represent an Uzbek nation? As hinted in the Introduction, the answer is essentially linked to the question of to whom the ethnonym "Uzbek" referred and how it was defined. Until the late nineteenth century, Uzbeks were perceived as descendants of nomadic tribes who had migrated from the

I7 Soucek 2000, p. I34.

I 8 In contrast, Vasiliy Barthold in I928 gave more weight to the "Persian" or "Iranian" influence on Alisher Navoi, characterizing the Timurid period as "a brilliant epoch in the cultural history of Persia and of the Turks - her masters in those days - and to it belong the finest monuments of Persian Muslim architecture [...]." Further on, Barthold suggested: "Mir Ali-Shir is perhaps the most brilliant representative of that particular current of the literary and cultural life of the Turks which is characterized by a complete surrender to the influence of 'Perso-Muslim' culture.” (I962 [I928], p. I; p. 5).

Babur I922, p. 4.

Starr 2013, p. 504.

Allworth I990, p. 37.

Ibid.

Ibid., p. 38. 
Dashti-Kipchak to the Mauverannahr region in the fifteenth-sixteenth century and settled there during the period of the Shaybani dynasty. These same Shaybanids were the invaders who brought about the downfall of the Timurid descendants. According to Alisher Ilkhamov, all peoples of Transoxiana began to be called Chagataids in the time of the decline of the Chagatai ulus, irrespective of their ethnic or tribal affiliation. This collective ethnonym differentiated the peoples under the Chagatai ulus from the people belonging to other Mongol uluses including the Uzbeks. ${ }^{25}$ In other words, "the term 'Chaghatay' ['Chagatai'] originally meant something distinct from the term 'Uzbek'." ${ }^{26}$ The ethnonym "Uzbek" came to be redefined when the modern term and concept of "nation" first entered Central Asia during the Russian colonial period.

The local elites who first laid the groundwork for the canonization of Alisher Navoi as an Uzbek national poet were the Central Asian Jadids or Muslim reformers who were influenced by a similar modernist movement instigated by the Crimean Tatar educator Ismail Gasprinski. They were also the first to imagine Central Asia according to the European notion of a nation. ${ }^{27}$ The nation or millat they had envisioned was a community that embraced Central Asian Turks who identified themselves as religiously and/or culturally Muslim and spoke in the Chagatai dialect. The Central Asian Jadids found a "political as well as regional symbolism" in Timur and his dynasty which served as their source of inspiration. ${ }^{28}$ Adeeb Khalid argues that Timur "who was a node where the Turco-Mongol heritage of the steppe, of Attila and Chinggis, came together with the Islamicate heritage of Central Asia" provided for the Jadids "both a heritage of state building and a golden age of high culture that a modern nation could claim." ${ }^{29}$ The Jadids also celebrated Alisher Navoi, who was a representative figure of this golden age of high culture and also a well-read author among Central Asian intellectuals. ${ }^{30}$ In I924, the long-standing local distinction between nomadic and sedentary population had been nationalized with the influx of modern ideas informed by European ethnographers and historians. ${ }^{3 \text { I }}$ By the time of the national delimitation, the ethnonym "Uzbek" came to designate the sedentary or urban Muslim Turks for the Jadid intellectuals who continued their efforts to create a national identity based on the glorious Timurid past and its literary treasures represented by the poet Alisher Navoi.

Establishing a national literature based on standardized literary language was a goal shared by the Jadid intellectuals, especially those who belonged to the Chagatai Circle

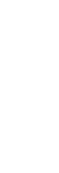

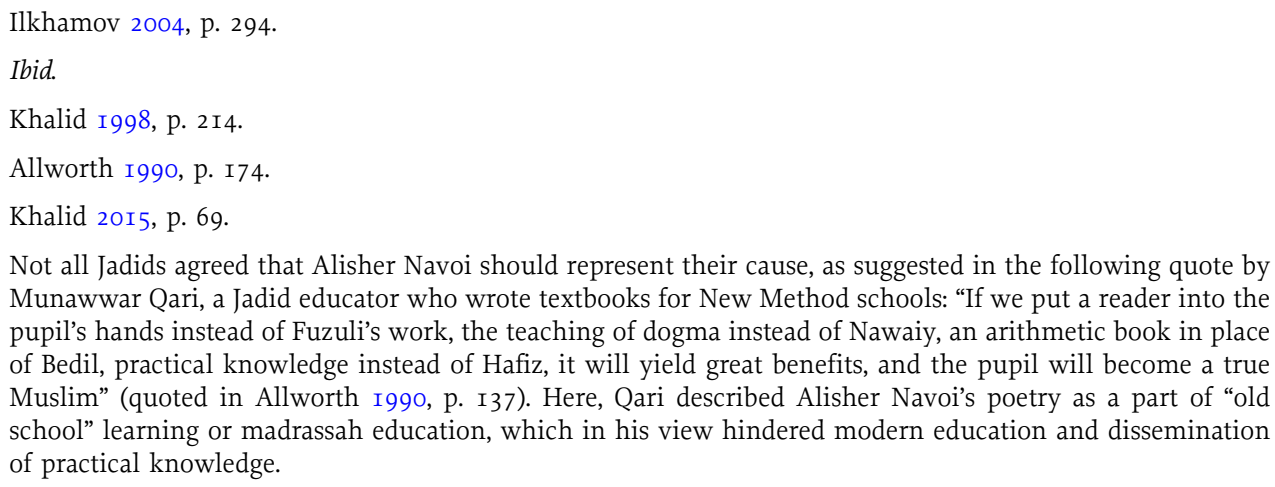
Munawwar Qari, a Jadid educator who wrote textbooks for New Method schools: "If we put a reader into the pupil's hands instead of Fuzuli's work, the teaching of dogma instead of Nawaiy, an arithmetic book in place of Bedil, practical knowledge instead of Hafiz, it will yield great benefits, and the pupil will become a true Muslim" (quoted in Allworth I990, p. I37). Here, Qari described Alisher Navoi's poetry as a part of "old school" learning or madrassah education, which in his view hindered modern education and dissemination of practical knowledge. Allworth I990, p. 269. 
(Chagatai Gurungi). According to Alisher Ilkhamov "the heritage of the Chaghataids' [Chagataid] age [lay] rather in culture - highly developed language and literature - than in groups of population that continued to call themselves Chaghatay [Chaghatai]". ${ }^{2}$ The Jadid members of the Circle, who were bilingual in Turkic and Persian and were from urban areas, believed that they had inherited the Chagatai cultural heritage and practised a restrictive pan-Turkism that embraced the areas where Chagatai language and literature had spread. ${ }^{33}$ The Circle's founder, Abdurauf Fitrat, thought that after the Arabic invasion destroyed the Turkic alphabet, Central Asian Turks had to adopt the Persian alphabet to write Arabic, which invited an overwhelmingly outside influence on Turkic literature. In Fitrat's words, Alisher Navoi was the poet who "strove hard to preserve the dignity of Turkic words" that had been replaced or dissembled to suit Arabic and Persian rhythmic styles and poetic conventions. ${ }^{34}$ In I928, a few years after the Uzbek SSR was established, Fitrat, in his anthology Models of Uzbek Literature (O'zbek Adabiyoti Namunalari), again named Navoi as one of the most prominent figures (with Babur, Bayqara, and Fuzuli) in the history of what he then called the "Uzbek-Chagatai" literature. Connecting Turkic literary canons of poets, including Yasavi (Yassawi) and Lutfiy, that came before Navoi's epoch with those that came after, he claimed that "Everyone knows that our province (o'lka) came to be called the Uzbek province (yurt) only in the sixteenth century, but the Turks had been living in Central Asia for long before then. They had their own independently developing literature which became Chagatai with the rise of the Uzbeks." 35 Fitrat also rejected the notion that the Chaghatai literary heritage belonged to the Iranian tradition and again emphasized the fact that even though Navoi was influenced by Persian cultural traditions, he advocated for the literary merit of the Turkic language that surpassed that of the Persian language. ${ }^{36}$

Abdurauf Fitrat's efforts to "write" a nation in a standardized literary language and Chagatai heritage had some effect on how the Uzbeks were imagined and distinguished from other Central Asian Turks. In I922, Nazir To'raqulov, the chair of the Turkestan Central Executive Committee (TurTsIK), commented: "A lot has happened in the past ten or fifteen years. Turkestanis have grown a great deal in this period. Everyone has recognised himself and his companions. The Uzbek has found Amir Navoiy [and] the Kazakh has caught hold of Abai." 37 To'raqulov's comments suggest that an Uzbek nation and Uzbek national consciousness developed along a different line from a Kazakh nation and Kazakh national consciousness. Indeed, Kazakh intellectuals, who had successfully established Kazakh and their own literary community, had no connection with nor made claims to Chagatayism. ${ }^{38}$ The Uzbeks, however, were not the only ones who "found" Alisher Navoi as To'raqulov had suggested. The newly established republics of Azerbaijan and

Ilkhamov 2004, p. 295.

33 Ibid., p. 305.

34 Fitrat 2009 [I92I], p. I33.

35 Fitrat 1928 , p. xi.

36 Fitrat I929, p. 43.

37 Quoted from Khalid 2015, p. 267.

38 Ibid., p. 266. 
Turkmenistan also celebrated the 5ooth anniversary of Navoi's birthday in I925 and designated the poet as a leading figure in the developments of Turkmen and Azeri literatures respectively. In I925, Ali Nazim, a prominent Azeri intellectual, published an article titled "Alisher Navoi and Us" (Alisher Navai ve biz) in which he venerated the poet from Herat for reasons similar to those Fitrat had done. ${ }^{39}$ According to Nazim, Navoi made "the first revolution in the Turkic people's literature which lacked the very idea of writing in the Turkic language.” The tone of the literary canonizations in the r920s, though, was quite different from that of the I930s. In the I920s, Soviet republican writers and intellectuals faced less pressure to inaugurate a national genius. By the same token, and with fair reasons, they could claim any literary or historic heritage as their own without being conscious of other Soviet friends and in the absence of a centralized watchtower. By the late I930s, however, literary canonization became a means of national categorization, as will be discussed further on in this article.

Not all Uzbek intellectuals, however, shared the view that Alisher Navoi could or ought to represent the new Uzbek nation. Local critics affiliated to the Uzbek Association of Proletarian Writers (UzAPP) rejected the idea of building a modern Uzbek literature based on Chagatai literary legacy and accused the Jadids of pan-Turkism and pan-Islamism. ${ }^{\circ}$ Dzh. Baibulatov, a Bolshevik critic, described Chagatai literature as "foreign to the contemporary Uzbeks" and that "the father of Chagatai literature who wrote in the introduction to his well-known divan ... that each first ghazal be adorned with the name of God and the glorification of His prophet" had no place in the modern Uzbek literature. ${ }^{4 I}$ Similar criticisms against the Chagatai Gurungi and its project were repeated by Rahmat Majidiy during the first Soviet Writers Congress held in I934. Majidiy attacked the Jadid intellectuals for forging a genealogical link between aristocratic Chagatai literature and modern proletariat Uzbek literature. He defined Chagataysm as a bourgeois nationalist and pan-Turkist movement that "idealised" and "proletariat-ised" the past. His criticism was directed mostly towards Fitrat and certain Alimukhamedov for attempting to incorporate religious mystics and feudal lords who were not even Turkic but Arabic or Persian into the new Uzbek literature for the sake of advancing Turkic nationalism. For local Bolshevik critics like Baibulatov and Majidiy whose views were influenced by the Leninist idea "two nations in one nation", the Uzbek nation was defined exclusively as a nation of Uzbek working class whose "national culture" had nothing to do with canons of the ruling class..$^{42}$ Therefore the critic proposed that young Uzbek

Quoted from Ülvi 2015 [I925].

See Allworth I964, pp. 52-56. In I9I9, the Musburo published a pamphlet titled Navois Thoughts about Humanity (Insoniyat Haqinda Navoiyning Fikr), which drew a sharp contrast between the old ulama or traditional political and religious elites and great thinkers of Central Asia including (as the title indicates) Alisher Navoi, Rumi, and Bedil. The pamphlet, which Adeeb Khalid suspects had been written by Fitrat, suggests the Jadids and Muslim Communists cooperated in the earlier years of the Revolution. Here, Alisher Navoi was used to advance not only Jadid reformist ideas but also Bolshevik agendas.

Baibulatov I929, pp. 99-III. Also see Baibulatov 1932.

According to Lenin (2008, p. 78), "The elements of democratic and socialist culture are present, if only in rudimentary form, in every national culture, since in every nation there are toiling and exploited masses ... But every nation also possesses a bourgeois culture in the form, not merely of 'elements', but of the dominant culture. Therefore, the general 'national culture' is the culture of the landlords, the clergy and the bourgeoisie" (italics mine). 
writers should pay closer attention to folklore, the literature of the people, instead of following the Jadid's bourgeois historicism. ${ }^{43}$ Alisher Navoi was, however, left unmentioned while Babur and Fuzuli were alluded to as examples of imposters in the new socialist history of Uzbek literature introduced by the Jadid nationalists.

\section{SOVIETIZING AN UZBEK POET: PREPARING FOR THE ALL-UNION ALISHER NAVOI JUBILEE, 1936-1948}

The earlier discourses on Uzbek national literature among Jadid scholars and Bolshevik critics had only limited influence on the Uzbek population, which had an official literacy rate of 3.8 per cent in I928.44 From the mid-I930s, however, the Soviet state made canonization of Alisher Navoi a state business and began to use more systemized and massive celebrations to inform and educate the Uzbek peoples as to who their national poet was. In I937, Moscow celebrated the first dekada or ten-day festival of Uzbek national culture, during which an operatic adaptation of Alisher Navoi's Farhod and Shirin was staged at the Bolshoi Theatre.45 In the following year, the People's Commissariat and the Communist Party of the Uzbek SSR acquired official approval from the Soviet People's Commissariat and the Central Committee of the Soviet Communist Party to celebrate the 5ooth birthday of the "Great Uzbek poet, Alisher Navoi" at the end of I94I.46 Qizil O'zbekiston, the Uzbek-language Party newspaper, announced the Soviet state's decision: "In I94I, the Uzbek People's Soviet Republic will hold a grand celebration for the 50oth anniversary of the birth of the great Uzbek poet Alisher Navoi." 47 The announcement explained: "Today, the state has shown much interest in the Uzbek literary heritage and its use. Having studied the history of our literature, the comrades came to the right conclusion." 48 In I937, a special committee for the Alisher Navoi Jubilee was created in Tashkent, while in Moscow, a committee that oversaw preparations for union-level republican writers' commemorations and arranged relevant celebratory events and publications in Russia was organized under the Soviet Writers' Union. The Tashkent Alisher Navoi Jubilee Committee included Russian Orientalists and prominent Uzbek scholars, writers, and artists as well as cultural administrators and political leaders including the then-First Secretary of the Uzbek Communist Party Usman Yusupov. ${ }^{49}$ However, the names of both the proponents and opponents of the earlier Alisher Navoi canonization discourses were absent from the list of the Committee's members. By then, Abdurauf Fitrat and his fellow Jadid intellectuals, as well as the local Bolsheviks including Baibulatov

43 Majidiy I994 [I934], pp. I26-36. Majidiy also reprimanded the Qizil Qalam (Red Pencil) or local proletariat writers who had failed to unite the people and to make socialist Uzbek literature interesting. Such criticisms marked a change of tide in the Soviet literary scene.

However, this figure dramatically rose to 52.5 per cent by 1932. Grenoble 2003, p. I43.

"Prazdnik Uzbekskogo Naroda," Pravda Vostoka, ıo March 1937.

O`zRMDA f. R-837, d. 33, op. 3I42, l. I.

"Ulug` O’zbek Shoiri Mir Alisher Navainin Toqulgariga 500-yil Munasavati Bilan Yubilei Komiteti Tuzish Haqida," Qizil O`zbekiston, I5 September I938.

48 Ibid. 
and Majidiy, had already vanished from the local literary scene, arrested and some executed for nationalist and anti-Revolutionary activities during the ongoing Stalinist Terror. They were replaced by a new Stalinist generation of writers who came to prominence with the establishment of the Uzbek Writers' Union. These young writers borrowed some of the previous generation's ideas on Alisher Navoi canonization and continued to build a Soviet-Uzbek literary history on the Chagatai literary heritage represented by Alisher Navoi.

According to Yuri Slezkine, "The ethnic groups that already had their own republics and their own extensive bureaucracies were actually told to redouble their efforts at building distinct national cultures" during the high Stalinist period of the I930s. Furthermore, "All officially recognised Soviet nationalities were supposed to have their own nationally defined 'Great Traditions' that needed to be protected, perfected and, if need be, invented by specially trained professionals in specially designated institutions." ${ }^{\circ}$ The official Soviet commemoration made previous literary celebrations of Alisher Navoi irrelevant. E. Bertel's, for example, called the I925 Turkmen and Azeri celebrations of Alisher Navoi "antiacademic" and "dangerous", because "the characteristic feature of the Navoi scholarship back then was that it almost exclusively was conducted by the representatives of nationalist bourgeoisie who sought to use [the poet's] name for their own advantages." 5 I Soviet celebrations of republican national writers widely promoted by the Soviet state also rendered "national exceptionalism" more pronounced, at least in the field of culture. The All-union commemoration of Alisher Navoi - like other similar celebrations of national poets and writers - confirmed to which Central Asian Soviet nationality the poet belonged. At a Nizami-Navoi Committee meeting held in Moscow in I940, an Azerbaijani representative commented: "My comrades and I did not know until last year that Alisher Navoi was an Uzbek poet. He had been considered as an Azerbaijani poet until now. [...] Navoi played a major role especially in the battle for the expulsion of Persian language from literatures of all Eastern peoples." ${ }^{2}$ A Russian Committee member reporting on the Jubilee preparations in Turkmenistan, Kirgizstan, Kazakhstan, and Azerbaijan made a similar remark regarding Turkmens: "[The republics] have organised special committees for the jubilee, the classical [poet] of Uzbekistan. I must say that for Turkmenia the poet is also regarded as their own classic[al poet]. Turkmens also consider Navoi as the forefather of their literature." 53 Hamid Olimjon, the Uzbek representative at the meeting and the then head of the Uzbek Writers' Union, interrupted the report and dismissed the Turkmen claim by suggesting that "Navoi was loved not only by the Turkic people (tiurki) but also by the Turkmens." 54

The celebrations of republican authors that "nationalized" literary figures whose influence and historical significance may cut across republican borders were held in the spirit of the "friendship of the Soviet peoples" expressed in the Soviet peoples' shared

\footnotetext{
50 Slezkine I994, pp. 444-47.

5 I Bertel's I965, p. 67.

52 RGALI f.63i, op.6, d. 447, 1. 45.

53 Ibid., 1. 43.

54 Ibid.
} 
understanding and appreciation for one another's national culture. A I940 Literaturnaia Gazetta article that was reprinted locally, for example, suggested that "For the wider Soviet public, each new literary jubilee [meant] not only learning something new of its poets but also to engage deeply with a lesson in history in all its aspects." 55 The article, which focused on reporting progress made on the Navoi Jubilee as well as a similar celebration of the "Azerbaijani national poet”, Nizami Ganjavi, also scheduled for I94I, celebrated the new opportunity presented by the October Revolution to revisit historical knowledge of the two nations and, more importantly, shared inspirations between the two Soviet national poets..$^{6}$ The most important friendship of the Soviet peoples, however, was the one between the Russian and a non-Russian nation that was demonstrated by Moscow's efforts to translate and circulate non-Russian republican works across the Soviet borders. Celebrating the Jubilee edition of Farhod va Shirin's Russian translation, Hamid Olimjon, who was involved in the translation, wrote: "For a poet-translator, there is no happiness like translating works of a world genius especially if the first translation is in the Russian language through which the immortal creations of Uzbekistan's brilliant classical work will become the cultural heritage of many other nations."57

Despite the fact that both the Soviet centre and republican governments often promoted the all-union level commemorations as an expression of Soviet friendship, the commemorations oftentimes revealed that republics were not familiar with or were simply indifferent to one another's national culture. For example, representatives from the Nizami Committee and the Navoi Committee univocally criticized Eastern European republics for making slow or almost no progress in translating the works of the Asian poets. ${ }^{8}$ Lev Pen'kovskii, a Russian member of the joint-Nizami-Navoi Committee, described an embarrassing incident by Literaturnaia Gazeta, which published Navoi's Farhad and Shirin on the same page as Bertel's' article on Nizami, "giving the impression that the two were related".59 Pen'kovskii complained that this incident, which caused "a complete muddle in the readers' heads", was a result of the newspaper editors' thoughtless decision to cut out the parts of Bertel's' article in which the author explained that Navoi's Farhod and Shirin came three hundred-some years after Nizami had worked on the same theme. The Uzbek and Azeri representatives complained that Literaturnaia Gazeta did not publish contributions by Uzbek or Azeri writers. ${ }^{60}$ According to Pen'kovskii, the main problem in Moscow was that "they [wrote] that there [would] be a Jubilee but for whom [was] not given a clear indication." 6 I

In contrast to the less than enthusiastic Moscow, Tashkent was fully mobilized for the Jubilee commemoration, which marked a milestone national event for the Uzbek cultural and literary elites. All republic-level cultural and academic institutions participated in the

M. Shaginisn, "Podgotovka k Uibileiu Alishera Navoi," Pravda Vostoka, 27 January I940.

56 Ibid.

Homid Olimjon, "Velikii Uzbekskii Poet, Myslitel', Uchenyi," Pravda Vostoka, 30 January I940.

58 RGALI f. 63I, op. 6, d. 447, 1l. 36-37.

59 Ibid., 1. 39.

60 Ibid.

6 I Ibid. 
Jubilee preparation. ${ }^{62}$ Tributes to Navoi were made in all available art forms. In addition to the publication project already discussed above, the Tashkent Jubilee Committee arranged several Western and folk musical performances, including a fully orchestrated opera based on Navoi's Leyli and Majnun. Several special exhibitions displayed objects related to Navoi's biography and poetry as well as artefacts from the pre- and post-Timurid eras. ${ }^{63}$ In addition, the Committee also held a contest for the best portraits of the Uzbek national poet. ${ }^{64}$ The winning portraits were reprinted on invitations sent out to cultural and academic figures across the Soviet Union as well as on stationery given out to school children as Jubilee gifts. ${ }^{65}$ The Committee also adopted plans to erect the poet's statue at the heart of Tashkent and to build several landmark architectures dedicated to or named after Alisher Navoi, including a museum, a state library, and a national opera and ballet theatre. ${ }^{66}$ The construction of these buildings was a part of the Uzbek state's ambitious project to transform Tashkent into a "cultured" Soviet city. ${ }^{67}$ As Paul Stronski has argued, the city of Tashkent "[was] to showcase Soviet innovation and technology" and "to show that the Revolution had transformed the Russian Empire into the Soviet Union [and] that this new state strove to move beyond its 'backward' past." 68 These new landmarks, that bore the name of the national poet and brought together elements of Socialist Realist aesthetics and traditional Uzbek ornaments, symbolized the modernized and nationalized Soviet Uzbek culture.

The Soviet canonization of Alisher Navoi transformed the poet from a sultan's fosterbrother, a feudal vizier (high-ranking minister), and a Sufi thinker into a prophet of the common folk who foresaw the coming of a socialist Uzbek nation. The writers who were involved in rewriting Alisher Navoi's biography came to erase not only the poet's religiosity, which had been a target of the earlier Bolshevik criticism, but also his class origin. Instead, they highlighted his closeness to the masses. In his "Navoi and the People", Hamid Olimjon described Alisher Navoi not only as a poet but also as a statesman who was "directly involved with caring for the people's welfare" and "sharply criticised wrongdoings of the state". ${ }^{69}$ Olimjon added: "Navoi was a true son of his era. At the same time, being a true scholar and great artist, he rose higher than his epoch and recognised that the country and the people could not remain in slavery and oppression for long. His soul ached for his people and his native land."70 Soviet critics also claimed that the masses had been the source of Alisher Navoi's poetic inspiration. An article on the I937 Uzbek dekada suggested that "The majority of [Navoi's] poems were based on popular legends much loved by

O`z RMDA f. R-837, op. 32, d. I356, ll. 22-23; O`z RMDA f. R-2356, op. I, d. 49, l. I5; “Film’ o Velikom Alishere,” Pravda Vostoka, 2 I April I94I.

63 "Vystavka, nosviashchenniia A. Navoi," Pravda Vostoka, 20 March I940.

64 O`z RMDA f. R-94, op. 5, d. 2543, 1l. 39-40.

O`z RMDA f. R-837, op. 33, d. 3I45, 1. 34.

O`z RMDA f. R-837, op. 33, d. 3I42, Postanovlenie no. 553.

67 Stronski 20Io, pp. 45-7I.

Ibid., p. 27.

Hamid Olimjan, "Navoi i Narod," Pravda Vostoka, 20 March I940. 
the Uzbek people."7I D. Osipov wrote in an introduction to Farhod and Shirin that "At the heart of this play is a 'tale' [and] it is unknown who first told this story, or where, and when," neglecting to mention that Alisher Navoi's Farhod and Shirin was a reworking of Nizami Ganjavi's Khosrow and Shirin, itself a story from the Persian epic Shahnama (Book of Kings). ${ }^{72}$

The Soviet celebration of Alisher Navoi was promoted as the returning of the poet who had previously been monopolized by the ruling elites and bourgeois nationalists to his rightful descendants, the Uzbek working people. At a Jubilee Committee meeting, Olimjon impressed on his colleagues that, "The sole responsibility to conduct truthful scholarship on Navoi's works, to correctly evaluate him and to implement progressive popularisation is [now] on us.... The people are eagerly waiting to learn about this great poet and we are obliged to provide them with answers." 73 Also, those in charge of the commemoration preparation claimed, "Until recently and especially during the pre-Revolutionary era, Alisher Navoi was only known by a closed circle of people [and] only an insignificant number of his works are published." 74 The Jubilee thus presented an opportunity for Uzbek citizens to learn how to "correctly appreciate" him as the Uzbek and Soviet national poet. Whether or not the claim held any truth, the Committee set popularization as one of its primary agendas and planned to publish between 10,000 and 30,000 copies of Hamza and lyrical poems from Chor-Divan in Uzbek. ${ }^{75}$ The Jubilee Committee, in collaboration with the Moscow Committee, also sent out translation orders and provided interlinear translations (podstrochnik) to all republics so that (ideally) selected works of Navoi would be published in all Soviet national languages for the commemoration.

The Alisher Navoi Jubilee, originally scheduled for I94I, took place in I948, three years after World War II had ended. Even before the war began, and with it the postponement of the Jubilee, both the Tashkent and Moscow Committees were unable to confirm the event's exact date. The participating institutions were often reprimanded by the Committees for their slow progress. ${ }^{76}$ The commemoration was postponed again indefinitely in July when the Soviet Union entered the war against Nazi Germany. The Jubilee Committee halted its operation, but some of its activities were continued for a different purpose; 77 the writers and scholars involved in the Navoi canonization were now mobilized for the task of promoting local patriotism for the Soviet motherland. By I947, preparations for the Jubilee had resumed. ${ }^{78}$

“Muzykal'nost' Iskusstvo Sotsialisticheskogo Uzbekistana,” Pravda, 2 I May I937.

"Farhad i Shirin: Postanovka Uzbekskogo Muzykal'nogo Teatra," Pravda, 24 May I937.

O`z RMDA f. R-2356, op. I, d. 79, l. I.

O`z RMDA f. R-86, op. Io, d. I452, 1. 48.

RGALI f. 63I, op. 6, d. 448, 1l. 66-67.

“Dostoino Vstrenim Yubilei A. Navoi," Pravda Vostoka, 20 March I940.

77

On recent studies on WWII propaganda in Soviet Central Asia, see Stronski 20IO; Berkhoff 20I2; Brandenberger 20I2; Manley 20I2; Carmack 20I4; Shin 20I5. On wartime Navoi scholarship, see Murodov I972. for the Jubilee celebration (O`z RMDA, f. R-837. Op. 33, d. 3I42, 1. 32). However, the archival document on the 
By I948, Alisher Navoi's status as the Uzbek national poet became indisputable. The Jubilee also marked an enunciative moment of Uzbek modernity (or, to be more exact, Sovietised Uzbek modernity). In I948, Oybek declared that Alisher Navoi had been rescued from unoriginality and neglect by the Soviets. During an Uzbek Writers' Plenum, Oybek asserted:

Now, Soviet science has proven that ... the Uzbek people ... had and have a distinct and original culture and that they are also creators of beautiful culture ... [science has also proven] that Alisher Navoi was not an imitator or translator but an independent poet who made significant contributions to the development of not only Uzbek literature but also literatures of other Central Asian and Asian literatures ... Navoi enriched not only literature of the East but literature of the world..$^{79}$

Here, Oybek rejected the idea that Central Asian literature, especially Uzbek literature, was founded by "copying" from other more advanced neighboring nations. On the contrary, Uzbek poets including Alisher Navoi were creators of beauty and masters of words who made a worldwide contribution. Yet, the Uzbek people had been unaware of their own creativity and originality. According to Oybek, before the revolution, "Education in Madrassas concentrated on memorising mechanically religious sciences, and therefore, poetry and literary monuments were lost." 80 "Only after the Bolshevik Revolution," the Uzbek writer claimed, "could people discuss poets and literary history." ${ }^{\mathrm{I}}$

From the Soviet centre's perspective, nationalization of Alisher Navoi may have assigned a historical prototype for the new Uzbek republic to build its own national culture distinguishable from other Soviet Central Asian nations, but not necessarily reduced the poet's regional significance. In other words, the Alisher Navoi Jubilee can be perceived as a part of the Soviet centre's "attempt both to respond to and to control the dynamic process of articulation of cultural difference, administering a consensus based on a norm that propagated cultural diversity." 82 After all, although the responsibility for the commemoration preparation and administration fell on the Uzbek SSR, the Jubilee was meant to be an all-Union celebration of a classical poet's inclusion into the Soviet Olympus of national geniuses. Yet, the reductionist-exclusivist - arguably nationalist - interpretation of Navoi's legacies became more obvious by the I948 Jubilee. Part of the reason for this was that the canonization of the poet as the forefather of Uzbek literature required an explanation as to how the poet - born, raised, and having spent most of his life in Herat, Afghanistan was related to the Uzbek nation. This ultimately raised the question of who the Uzbeks were. In addition, World War II, which interrupted the Jubilee Committee's works,

post-WWII Jubilee preparations suggests that the actual preparation resumed much earlier in I947 (O'z RMDA, f. R-837, op. 33, d. 3I40, 1l. I64-65).

O’z RMDA f. R-2356, op. I, d. I4I, l. I9I.

RGALI f. 63I, op. 34, d. I68, ll. I-2.

8 I Ibid.

82 Rutherford I990, p. 208. 
nevertheless strengthened such reductionist-exclusivist claims of national ownership by encouraging the local elites who were assigned to produce war propaganda to reconnect with (even reconstruct) the pre-Revolutionary history of the Uzbek nation.

\title{
DISCOURSES ON THE ORIGIN OF THE UZBEK NATION AND WARTIME HISTORY RE-WRITING
}

In I940, Homid Olimjon emphasized the significance of the Alisher Navoi Jubilee in the following words: "For us, the question of learning Navoi's art has become such an essential question that it determines the whole history of Uzbek literature and the Uzbek people. We believe that the Jubilee will give us the opportunity to establish the history of the Uzbek nation." ${ }_{3}$ As suggested by Olimjon's statement, nationalizing Navoi entailed much more than simply establishing a literary canon. It brought to public attention the question of who the Uzbeks were in antiquity. By 1947, however, this question seemed to have been resolved. At an Uzbek Academy of Sciences meeting held in 1947 on the topic of Alisher Navoi and his time, the participants seemed to have reached a consensus that Alisher Navoi did not mark the beginning of Uzbek literature and that the history of the Uzbek people went far back to ancient times. ${ }^{84}$ Criticizing P. Skosyrev for publishing an incorrect understanding of Uzbek ethnogenesis and creating confusion by suggesting that Uzbek literature began with Navoi, Tushmukhamed Sarymsakov, the chair of the Uzbek Academy of Sciences, commented that "Even though Iakubovskii and many scholars have comprehensively proven that the Uzbek people first made an appearance [in Central Asia] in ancient times ... there are those who still argue that the Uzbek people came [to Central Asia] only during the sixteenth century." ${ }_{5}$ Oybek, the then-head of the Uzbek Writers' Union, further elaborated the historical significance of Alisher Navoi in the following words:

\begin{abstract}
Historical and literary evidence shows that Uzbek literature came into existence several centuries before Navoi and had gradually progressed [...] Akhmad Iassavi (Ахмад Яссави), Suleiman Bakyrgani (Сулейман Бакыргани), Rabguzi (Рабгузи), Khorezmi (Хорезми) also played a crucial role in the development of the Uzbek literary language. Then what is so special about Alisher Navoi? ... In order to refine the "crude-steppe” Uzbek language into a literary language, it must be transformed into the language of a state. Alisher Navoi achieved precisely this. ${ }^{86}$
\end{abstract}

The primordialist claims of the Uzbek people's origin made by possibly the two most influential figures of the post-WWII Navoi Jubilee Committee were largely informed by the Russian orientalist Aleksandr Iakubovskii's view on the Uzbek ethnogenesis published

\footnotetext{
83 RGALI f. 63I, op. 6, d. 447, l. 4I.

84 RGALI f. 63I, op. 34, d. I68, 1l. 6.

85 Ibid., l. 3.

86 Ibid., l. 4.
} 
in April I94I, right before the Soviet Union entered World War II, or the Great Patriotic War. ${ }^{87}$

In I94I, a conference was organized to discuss the question of the Uzbek people's origin and to provide a better historical understanding for those involved in the commemoration preparation. ${ }^{88}$ Aleksandr Iakubovskii was invited to give a lecture that explained how the modern Uzbek people were connected to Alisher Navoi and his legacies. Iakubovskii found it "unfortunate" that the view that "the Uzbek people originated from the nomadic-Uzbek, who appeared in Central Asia in the fifteenth century and conquered it under the leadership of Shaybani khan only in the beginning of the sixteenth century" was still prevalent among Soviet historians. ${ }^{89}$ Iakubovskii proposed an alternative understanding of the Uzbek people's origin by suggesting that the nomadic Uzbeks were assimilated into the indigenous inhabitants who had settled in the territory of modern Uzbekistan since ancient times. The ethnonym "Uzbek" which originated from the newcomers was given to the group born out of inter-ethnic and inter-cultural marriages between the two groups. ${ }^{90}$ Iakubovskii thus "differentiated between the historical conditions of national formation and the appearance of the ethnic name, enabling specialists to postulate autochthonous origins for republics in distant epochs before the peoples were known by their contemporary names (my italics)".9I Applying a similar logic of autochthonism, Uzbek national culture could be perceived as a product of historical accumulation of cultural achievements made by different Turkic and Tajik peoples that had lived in the territory of Uzbekistan. ${ }^{22}$ Iakubovskii asserted: "[Alisher Navoi] could not have [been] born on a soil devoid of cultural traditions. [...] Roots of his creations branch out to various Turkic languages and literatures that [made] their own rich histories within the territory of Uzbekistan and in neighboring regions until the fifteenth century."93

When discussing Uzbek cultural formation, Iakubovskii employed a flexible concept of territoriality instead of a rigid concept of territory. Characterizing the Uzbek culture as "urban Turkic" allowed this territoriality to expand along the cities of Samarkand, Tashkent, and Bukhara as well as Balkh and Herat in Afghanistan, incorporating the areas that did not fall within the Uzbek territory but had historically and predominantly

87 Francine Hirsch (2005, p. I 27) explains that Russian and Soviet ethnographers "conceived of nationalities as ethno-historical groups that took form through a process of ethnogenesis, and ... attempted to determine which clan, tribes, and narodnosti had evolved and amalgamated into which narodnosti or natsional'nosti."

O`z RMDA, f. 2356, op. I, d. 79, 1l. I-2.

Iakubovskii I94I, p. 3.

Ibid., pp. 3, I8-I9. Shoshana Keller demonstrates how later Soviet textbooks of Uzbek history ignored the question of where the Uzbeks had come from based on Iakubovskii's theory of Uzbek ethnogenesis. According to Keller, textbooks for older students discussed the descent of Turkic tribes called Uzbeks from the northwest of China and their integration with Iranian-speakers in Transoxiana. Yet, the textbooks declared that, "On the territory of contemporary Uzbekistan, the Uzbek nationality had formed by the tenth-eleventh centuries, calling themselves Central Asian Turks as distinct from the Turkmen and other Turkic-speaking peoples" (quoted in Keller 2007, p. 272). Concerning the Shaybani invasion, the books explained that Shaybani's horde "became a new element entering into the structure of the ancient Uzbek people that had formed here in the eleventh-twelfth centuries" (pp. 272-73).

Bustanov 20I5, p. 5I.

Iakubovskii I94I, pp. I3-I8.

Ibid., p. I8. 
been influenced by the people who came to be known as "Turkic" or "Uzbeks".94 Iakubovskii credited the Timurid dynasty for playing an especially significant role in the process of cultural accumulation by giving rise to "urban life and sedentary culture" in Transoxiana. 95 Iakubovskii's thesis was widely accepted by both the local Uzbek cultural elites as well as evacuated scholars who collaborated with their Central Asian counterparts during the war. ${ }^{6}$ In 1942 , Soviet ethnographers and anthropologists gathered to discuss the ethnogenesis and historiography of Central Asian ethnic groups. The conference participants, who explored possible dynastic or tribal lineage that could serve as an evidence of ethnic continuity for each Central Asian titular nationality and as a reference used when identifying the historical period in which the nation's formation had completed, came to the consensus that the Uzbek nation was most closely identified with the Turkic people in terms of ethnicity (genealogy) and with the Timurids in terms of dynasty (cultural legacy). 97

As Alisher Ilkhamov notes, however, Aleksandr Iakubovskii's idea of ethnogenesis could be considered as "plagiarism" for "it reproduced the views of the Jadids who were the first to consolidate the history of Turkestani people from the times of the Timurids, Chenghiz-khan [Chinggis] and the pre-Mongol period". ${ }^{98}$ His emphasis on the historical accumulation of culture that expanded beyond the national territory of Uzbekistan also resonated with Abdurauf Fitrat's pan-Turkist veneration of Chagatai literary legacy and preserved the early I930s Bolshevik criticism against historicism. But, more importantly, Iakubovskii restored (or invented) a part of pre-Revolutionary history that had been shunned during the Stalinist I930s. It is no accident that the thesis was published in the summer the Nazi invasion of the Soviet Union began. ${ }^{99}$ The Soviet state at war now required the service of national history for the promotion of Soviet patriotism based not only on the spirit of the Soviet friendship but also on heroic nationalism. The wartime exigencies and challenges led to further heroization of Alisher Navoi and veneration of national heroes from the restored history of the nation.

During the war, Uzbek propaganda cadres that included mobilized writers and scholars faced the challenge of cultivating Soviet patriotism among the local population. As Paul Stronski has noted, earlier attempts to build war propaganda based on images of Russian nationalism and Russian historical figures proved to have little positive effect on the local population. The local propagandist localized the war through using Central Asian

94 According to Iakubovskii, "Turkic assimilation to the urban culture that had been created by the Tajik-speaking population occurred rapidly in Central Asia and especially in Uzbekistan starting from the Karakhanid period. This entailed not only the Turks learning the Tajik-Persian language and Iranian literature, but also the Turks participating in the construction of an urban material culture. [...] Unfortunately, the uniform name of 'Muslim' does not give the possibility of distinguishing to which nation a master whose name is preserved in monuments be designated. [...]" (Ibid., pp. I3-I8).

Ibid., pp. IO-I 2.

Bustanov 20I5, p. 52.

Laruelle 2008, p. I75; Tolstov I947, pp. 303-5; Gerasimov I947, p. 3 I4. 
historical motifs and glorifying "Uzbek warriors" who defended Central Asia. ${ }^{\text {Iоo }}$ As a consequence, the evacuated and local cultural elites "dug into" the pre-Bolshevik history of the Uzbek nation. Alisher Navoi was also used as the symbol of the Uzbek nation as shown in a widely circulated poster. Soviet Red Army soldiers and Alisher Navoi were positioned so that the poet was guarded by snipers. Navoi's words - "As long as a man is alive, he must protect his motherland with his last strength" - were taken out of context and paired with a clause from the 1936 Soviet Constitution, which obliged every Soviet citizen to take up arms for the defence of Soviet soil. ${ }^{\text {го }}$ The Soviet Union and the Uzbek nation were thus converged through the poet's symbolism. The poet also frequently appeared in newspaper articles in which he was described as a "statesman of pen and sword", as in Shayxzoda's piece on Uzbek literary history, where the poet is frequently described as "[holding] a pen in one hand and a sword in another". ${ }^{\text {102 }}$

Alisher Navoi was a foolproof national symbol whose official canonization began well before the war, but he was not necessarily a militaristic hero. Therefore, the Uzbek cultural and political elites dug into history in search of heroes for the nation at war. The elites found the concepts of autochthonism and territoriality appealing and incorporated them into their rewriting of Uzbek history. Historical figures, especially those who made their names in history as victors, conquerors, and rulers were revived in local wartime literature. Uzbek writers composed biographical and historical fictions, including Olimjon's Muqanna [Mukanna], Oybek's Mahmud Torobi [Makhmud Tarabi], and Shayxzoda's Jaloliddin Manguberidi [Jalaladdin]. ${ }^{\text {103 }}$ Muqanna was about al-Muqanna who resisted the Arab imposition of Islam in the eighth century, while Mahmud Torobi was a biographical prose account of Tarabi, an artisan who lived during the thirteenth century and led a peasant uprising against the Mongol rulers. Jalal-ad-Din, the hero of Shayxzoda's Jaloliddin Manguberidi, was the last ruler of Khwarezmian Empire who also fought against the Mongols in the thirteenth century. Olimjon drew a genealogical link that connected the historical heroes with the modern-day Uzbeks, claiming that "My people have good control of weapons [because] for a thousand years, they fought against enemies. The soul of Muqanna who chased the retreating Arab invaders and the soul of Tarabi, who rose up against the terror of Chingiz khan, are still alive. Today, Uzbek soldiers go to battles with the names of the people's heroes on their lips." I04

The authors of these historical fictions sometimes trivialized historical accuracy and compromised ideological correctness for the sake of promoting patriotism. For example, Oybek's Tarabi survives the battle against the Mongols contrary to what history suggests. The class origin and ethnicity of the heroes were also overlooked: Muqanna was a Persian from Merv, while Jalal ad-Din Manguberdi was a prince. It was only after the end of the Great Patriotic War that such historical misrepresentations became problematic. In I945,

\footnotetext{
Ioo As Stronski (20Io, p. 79) argues, "Propaganda still declared Amir Timur (Tamerland) or the emirs of Bukhara to be historical oppressors of the Uzbek peoples [...]."

Ior OzRMvSIV (Ministry of Culture and Sports of the Republic of Uzbekistan) achieve IZ.Ko-33.Imb.29o.

I02 Shayxzoda, "Patrioticheskaia Muza Uzbekistana," Pravda Vostoka, 6 September i944.

I03 Olimjon's Muqanna and Shayxzoda's Jalaladdin were plays, whereas Oybek's Makhmud Tarabi was written as a libretto (Kedrina and Kasymov I967, pp. 219, 225).

I04 Olimjon I960, p. II9.
} 
at a meeting held at the Uzbek Writers' Union, Oybek had to defend what he called "the mood of the time" against the criticism that he had distorted historical facts during the war:

Our comrades were facing the situation that called for [literature] that could inspire the people to fight for their country, even if the stories did not correspond with historical facts. ... We had to produce [literature] that would pour new strength and faith in victory into the hearts of our people. ${ }^{\text {I05 }}$

Other writers who had worked on historical fiction were also criticized for glorifying heroes who won their victory by ruthlessly conquering and terrorizing ancestors of a "Soviet friend", a Soviet titular national group, a contradiction often overlooked during the war. Komil Yashin made the following comments concerning Jaloliddin Manguberidi:

We have to come to a common conclusion about who this Jalaladdin really was a hero who protected his homeland or an oppressor? However, this issue goes beyond the control of our Writers' Union. Our writers portray him as a hero and the Georgian and Armenian writers portray him as a cruel oppressor. ${ }^{\text {Io6 }}$

The meeting revealed that, when it concerned historical fiction writing, Uzbek nationalism took precedence over the Soviet Friendship so fervently promoted during the war. ${ }^{107}$ To conclude the debates on Jaloliddin Manguberidi and its (alleged) misrepresentation of history, Oybek asserted: "We all knew about Jalaladdin through the perspectives of our historians. In these historical documents written in Persian, Arabic, and Turkic, he appeared as a king and a hero of the people who led national masses against the Mongol horde. He was a true son of his motherland." ${ }^{\circ 8}$ Although Oybek agreed that it would have been better if the Uzbek writers had learnt about how the peoples of the Caucasus remembered Jal-al-Addin, he nevertheless praised the play Jaloliddin Manguberidi as one of the best Uzbek plays written during the war years. ${ }^{\text {I09 }}$

In addition to the wartime exigencies and the goal of promoting Soviet patriotism, the inevitable decentralization of authority during the war seemed to have allowed the republican writers to prioritize national sentiment over Soviet internationalism. In I944, the Soviet Writers' Union held a Plenum to discuss wartime literary and publishing activities in the republics. One of the speakers addressed the problem that the Soviet Writers' Union was not aware of what was happening in the brother republics because the publishers did not print Russian translations of republican literatures. ${ }^{\text {I } ~}$ Another speaker raised the issue that there could really not be "literary criticism" during the war because wartime literature

I05 O`z RMDA f. R-2356, op. I, d. 58, l. Iо.

I06 Ibid., 1. 6.

I07 For wartime propaganda constructed around the idea of the friendship of the Soviet peoples, see Tillet I965, pp. 58-83; Manley 20I 2, pp. 220-37.

Io8 O`z RMDA f. R-2356, op. I, d. 58, 1. I8.

I09 Ibid.

I IO RGALI f. 23, op. II, d. $44,1.3$. 
was so much loved by the masses. ${ }^{\text {II }}$ Although the Plenum documents did not reveal exactly what the Soviet Writers' Union thought was problematic, it is hinted that the republican writers enjoyed some degree of leniency. During the immediate post-WWII years, the Soviet centre expressed its concern regarding wartime cultural developments in the republics and called for a reassessment of wartime Central Asian and Caucasus scholarship. In 1948, the Soviet Writers Union sent out a letter requesting writers and scholars in Central Asia and the Caucasus to re-evaluate works of national literature and historical scholarship. The Writers Union's main concerns were that the republic literary scholarship and historical literature written during the war "did not fully uncover the aspect of class-struggle" and failed to discuss "the leading role of the Russian culture in the development of contemporary Soviet and pre-Revolutionary democratic literature of the peoples of the East." ${ }^{\prime 2}$ The Writers Union also addressed the issue of conflicting national exceptionalist claims:

Often contradictory interpretations arise when one and the same literary monument or folklore is claimed by not one but two or even several nations. Such claims for exclusive possession by one and no other people and the consequent contradictions have surfaced concerning, for example, Avesta (in the original 'Авеста') and the epoch of Kitabi Dede Kordud ('Китаби деде Кордид). ${ }^{\text {Iз }}$

The Writers Union suggested organizing a debate (diskussiia) hosted in Moscow to settle the disputes concerning national(ist) ownership of cultural and literary legacies once and for all. Works on Uzbekistan that were reassessed included local and Russian scholarship on Timurid-period poetry and Oybek's fictional and non-fictional biographies of Alisher Navoi. However, such attempts by the Soviet centre to resolve possible disputes over cultural and literary heritage had little effect on the Uzbek canonization of Alisher Navoi as the Uzbek national poet. Instead of reassessing national claims made about Alisher Navoi, the Uzbek Writers Union decided to publish a collection of poems dedicated to Navoi by contemporary Uzbek authors. ${ }^{\text {II } 4}$ The collection, which was to be titled Poets of Uzbekistan on Navoi (Poety Uzbekistana o Navoi), started out as a more ambitious project, which would have included all odes and literary dedications made to Alisher Navoi by poets and scholars from Uzbekistan since Novoi's own time. ${ }^{\text {II } 5}$ Thus, the Soviet Uzbek writers established a genealogical link between Alisher Navoi from Timurid Herat and rising young talents of the socialist Uzbek nation, as did the Jadid Chatagai Circle intellectuals who also considered themselves to be inheritors and transmitters of his literary and cultural legacies.

I I I Ibid., 1. 4.

II 2 O’z RMDA f. R-2356, op. I, d. I46, 1. 58.

I 3 Ibid.

I 4 Ibid., 11. 62-64.

II5 O'z RMDA f. R-837, op. 33, d. 3I45, 1. 34. Because there was a lack of time and not enough materials from the pre-Revolutionary era fitting the theme, the Jubilee Committee changed its plan to publish an anthology of Uzbek poetry and released a collection of Navoi odes by Soviet Uzbek writers instead. 


\section{CONCLUSION}

This article has explored how sovietization of Uzbek literature - or Soviet nation-building through the creation and celebration of a national genius - led to uzbekification of Alisher Navoi, a fifteenth-century poet from Herat, Afghanistan, who had exerted significant influence on the development of Central Asian Turkic language and culture. The decade-long preparation for the Soviet canonization established Alisher Navoi as a symbol of Uzbek exceptionalism and uniqueness that distinguished the Uzbek nation from other Central Asian nations. The process of nationalizing Alisher Navoi also ascribed ownership to the Uzbek nation over Chagatai and Timurid cultural legacy. Notwithstanding the possible historical misrepresentation of the region's history, Soviet and Uzbek cultural elites successfully transformed Nizam-al-Din Ali-shir Harawi of Herat to Alisher Navoi of Tashkent between the I920s and the late I940s. ${ }^{\text {I } 6}$ The Uzbek appropriation of the Timurid historical and cultural legacies Alisher Navoi represented was justified by the Russian orientalist Aleksandr Iakubovskii's theory of the Uzbek ethnogenesis and autochthonism. Iakubovskii separated the ethnonym "Uzbek" - the name of the nomadic Turco-Mongolian tribe who had driven out the Timurids in the sixteenth century - from the historical inhabitants of Uzbekistan. Simply put, he promoted the idea that all peoples who had resided in the Uzbek territory belonged to the Uzbek nation.

Iakubovskii's thesis helped the Uzbek propaganda producers, who were given the task of promoting Soviet patriotism among the Uzbek population, to venture further back into Central Asia's pre-Revolutionary history of Central Asia in the search for an Uzbek national hero. The wartime exigencies that led to the decentralization of censorship also allowed the local propaganda cadres and writers to compromise ideological correctness and historical accuracy for the sake of unifying the Uzbek nation. When Moscow regained its centrality after the war ended, it attempted to reverse some of the wartime nationalization of cultural heritage and rewriting of national historiography. Nevertheless, the national heroes who had been revived during the war entered the Uzbek history textbooks as national heromartyrs, as shown in Shoshana Keller's study of I950s Soviet Uzbek history education. Keller writes: "These martyrs provided a proud and ancient genealogical line for the entire Uzbek people [...]." II7

As suggested by Oybek's celebratory remarks, the poet as well as the Uzbek people had been "rescued" or "rediscovered" by (not fraternal Russians but) the Soviet state. This rhetoric of "rescue" concealed the fact that there had been earlier attempts at nationalizing Alisher Navoi and building a national literature based on his legacy prior to the Soviet (re)discovery of the poet. The I930s and I940s canonization of Alisher Navoi was not a rootless imposition of culture and history unfamiliar to the later generation of Uzbek cultural and literary elites. Perhaps the ritualized Soviet celebration of a literary genius that had mobilized all state cultural and scholarly organizations in the republic may have been new. But Navoi and his poetry had already been a part of a local nation-building project that was begun in the early I920s by the Jadid intellectuals. The earlier scholarship by

II6 Allworth I964, pp. 229-30.

I 7 Keller 2007, pp. 274-75. 
the Chagatai Gurungi Jadids on Navoi and Central Asian that was very similar to Aleksandr Iakubovskii's idea of ethnogenesis, however, had to remain concealed behind the covers of censored books until the Soviet collapse. Today in post-Soviet Uzbekistan, Keller writes, "Timur Lang and Alisher Navoi have become the cornerstones of an aggressive story of Uzbek national achievements that owes nothing to Russia” or to the Soviets. ${ }^{\text {II } 8}$ The Jadids, on the other hand, have been venerated as conscious intellectuals who resisted the Soviet indoctrination and distortion of national history.

\section{REFERENCES}

\section{Uzbek State Central Archive (O’zRMDA)}

f. R-86, op. Io, d. I452.

f. R-837, op. 32 , d. I356.

f. R-837, op. 33 , d. 3 I 42 .

f. R-2356, op. I, d. 49 .

f. R-2356, op. I, d. 58 .

f. R-2356, op.I, d. 79 .

f. R-2356, op. I, d. I4I.

f. R-2356, op. I, d. I46

\section{Russian State Archive of Literature and Arts (RGALI)}

RGALI f. 23, op. II, d. 44 .

RGALI f. 63I, op. 6, d. 447.

RGALI f. 63I, op. 6, d. 448.

RGALI f. 63I, op. I5, d. 472.

RGALI f. 63I, op. 34, d. I68.

Adams 2010

Adams, Laura. The Spectacular State: Culture and National Identity in Uzbekistan. Durham: Duke University Press, 2010.

Allworth I990

Allworth, Edward. The Modern Uzbeks: From the Fourteenth Century to the Present. Stanford: Hoover Institution Press, I990.

Allworth r964

Allworth, Edward. Uzbek Literary Politics. The Hague; London: Mouton, I964.

Asadova 2014

Asadova, Shoira. "Osnovnye kharakteristiki covetskoi ictoriograficheskoi shkoly v Uzbekistane." In Istoriia I Istoriki Uzbekistana $v$ XX beka. Tashkent: Navro`z, 2014.

Baibulatov 1932

Baibulatov, Dzh. Chagataizm-panturkism v uzbekskoi literature. Moscow: Ob'edinenie gosudarstvennykh izdatel'stv sredneaziatskoe otdelenie, I932.

Baibulatov I929

Baibulatov, Dzh. “Uzbekskaia literatura i chagataizm.” Pechat i revoliutsiia 9 (I929), pp. 95-I03.

Babur I922

II8 Ibid., p. 277. 
Babur. Baburnama: Memoirs of Babur, trans. Annette Beveridge. London: Luzac \& Co, I922.

Barthold I962 [I929]

Barthold, Vasilii. Four Studies on the History of Central Asia, vol. 3. Leiden: Brill, I962 [I929].

Berkhoff 2012

Berkhoff, Karel. Motherland in Danger: Soviet Propaganda during World War II. Cambridge: Harvard University

Press, 20I 2.

Bertel's I965

Bertel's, E. "Navoi," Izbrannye trudy: navoi i dzhami. Moscow: Akademiia Nauka SSSR, I965.

Brandenberger 2012

Brandenberger, David. National Bolshevism: Stalinist Mass Culture and the Formation of Modern Russian National Identity, I93 I-I956. Cambridge, MA: Harvard University Press, 2012.

Bustanov 2015

Bustanov, Alfrid K. Soviet Orientalism and the Creation of Central Asian Nations. New York: Routledge, 2015.

Carmack 20I4

Carmack, Roberto. "History and Hero-making: Patriotic Narratives and the Sovietisation of Kazakh front-line Propaganda, I94I-I945." Central Asian Survey 33:I (2014), pp. 95-I22.

Corse I997

Corse, Sarah. Nationalism and Literature: Culture in Canada and the United States. Cambridge: Cambridge Press. I997.

Fitrat 2009 [I929]

Fitrat, Abdurauf. “Adabiyot qoidalari.” In Tanlangan asarlar, pp. I I-88. Tashkent: Ma`naviyat, 2009 [I929].

Fitrat 2009 [I929]

Fitrat, Abdurauf. “Chigłatoy adabiyoti.” In Tanlagan asarlar 2-jild, pp. 37-44. Tashkent: Ma`naviyat, 2009 [I929].

Fitrat 2009 [I92I]

Fitrat, Abdurauf. "Muqaddimat ul-adab.” In Tanlangan asarlar, pp. I3 I-35. Tashkent: Ma`naviyat, 2009 [I92I].

Fitrat 2009 [I9I9]

Fitrat, Abdurauf. "She`r va shoirliq." In Tanlangan asarlar, pp. 5-II. Tashkent: Ma`naviyat, 2009 [I9I9].

Fitrat 1928

Fitrat, Abdurauf. O`zbek Adabiyoti Namunalari. Samarkand, I928.

Gerasimov I947

Gerasimov, M. M. "Vosstanovlenie tipa iskopaemogo cheloveka i ego znachenie dlia resheniia voprosa etnogeneza uzbekov." Sovetskaia etnografiia 6:7 (I947), pp. 313-14.

Grenoble 2003

Grenoble, Lenore A. Language Policy in the Soviet Union. Dordrecht: Kluwer Academic Publishers, 2003.

Grousset I970

Grousset, Rene. Empire of the Steppes: A History of Central Asia, trans. Naomi Walford. New Brunswick: Rutgers University Press, I970.

Hirsch 2005

Hirsch, Francine. Empire of nations: Ethnographic Knowledge and the Making of the Soviet Union. Ithaca: Cornell University Press, 2005.

Iakubovskii I94I

Iakubovskii, Aleksandr. K voprosu ob etnogeneze uzbekskogo naroda. Tashkent: Izdatel'stvo UzFan, I94I.

Ilkhamov 2004

Ilkhamov, Alisher. “Archaeology of Uzbek Identity.” Central Asian Survey (2004), pp. 289-326.

Kedrina and Kasymov I967

Kedrina, Z. and S. S. Kasymov. Istoriia uzbekskoi sovetskoi literatury. Moscow: Nauka, I967.

Keller 2007

Keller, Shoshana. "Story, Time, and Dependent Nationhood in the Uzbek History Curriculum." Slavic Review 66:2 (2007), pp. 267-77.

Khalid 20I5

Khalid, Adeeb. Making Uzbekistan: Nation, Empire, and Revolution in the Early USSR. Ithaca: Cornell University Press, 20I5.

Khalid I998 
Khalid, Adeeb. Politics of Muslim Cultural Reform: Jadidism in Central Asia. Berkeley: University of California Press, I998.

Kurzman 1999

Kurzman, Charles. "Uzbekistan: The Invention of Nationalism in an Invented Nation." Critique: Critical Middle Eastern Studies 8 (1999), pp. 77-98.

Lenin 2008

Lenin, Vladimir. On Literature and Art. Rockville, MD: Wildside Press, 2008.

Laruelle 2008

Laruelle, Marlene. "The Concept of Ethnogenesis in Central Asia: Political Context and Institutional Mediators (I940-50)," trans. Stephanie M. Lin. Kritika 9:I (2008), pp. I69-88.

Majidiy I994 [I934]

Majidiy, Rahmat. "Doklad R. Madzhdi [Majidiy] o literatury uzbekskoi sss.” In Pervyi vsesoiuznyi s'ezd sovetskikh pisatelei 1934: stenograficheskii otchet, ed. I. K. Luppol, pp. I27-28. Moscow: Sovetskii Pisatel', I934.

Manley 2012

Manley, Rebecca. To the Tashkent Station: Evacuation and Survival in the Soviet Union at War. Ithaca: Cornell University Press, 2012.

Mirzaeva 2015

Mirzaeva, Zulkhumor. "Criticism as War: The Ideological Battlefield of Uzbek Literary Studies from the I950s to the I99os." Cahiers d' Asie Centrale (2015), pp. 267-9I.

Murodov I972

Murodov, M. Navoiyshunoslar Zhacorati. Tashkent: Fan, I972.

Nazarov et al. 2012

Nazarov, B. et al. O`zbek Adabiy Tanqidchiligi Tarixi, Tashkent: Cholpon nomidagi nashriyot-matbaa ijodiy uyi, 2012.

O`zbek Respublikasi Oliy va O`rta Maxsus Ta`lim Vazirligi 2004

O’zbek Respublikasi Oliy va O`rta Maxsus Ta’lim Vazirligi, Lotin Yozuviga Asoslangan O’bek Alifbosi va Imlosi (O`quv Qo`llanma), Tashkent: Toshkent Moliya Instituti, 2004.

Pravda

Pravda, Moscow.

Pravda Vostoka

Pravda Vostoka, Tashkent.

Qizil O’zbekiston

Qizil O`zbekiston, Tashkent.

Rutherford I990

Rutherford, Jonathan. "Interview with Homi Bhabha." Identity: Community, Culture, Difference, pp. 207-2 I. London: Lawrence and Wishart, I990.

Shin 2015

Shin, Boram. "Red Army Propaganda for Uzbek Soldiers and Localised Soviet Internationalism during World War II." Soviet and Post-Soviet Studies Review (20I5) pp. 39-63.

Slezkine I994

Slezkine, Yuri. "The USSR as a Communal Apartment or How a Socialist State Promoted Ethnic Particularism."

Slavic Review 53 (I994), pp. 4I4-52.

Soucek 2000

Soucek, Svatopluk. A History of Inner Asia. Cambridge: Cambridge University Press, 2000.

Starr 2013

Starr, Frederick S. Lost Enlightenment: Central Asia's Golden Age from the Arab Conquest to Tamerlane. Princeton: Princeton University Press, 2013.

Stronski 2010

Stronski, Paul. Tashkent: Forging a Soviet City, I930-1966. Pittsburgh: University of Pittsburgh Press, 2010.

Subtelny I988

Subtelny, Maria. "Socioeconomic Bases of Cultural Patronage under the Later Timurids." International Journal of Middle East Studies 20:4 (I988), pp. 479-505. 
Tillet 1965

Tillet, Lowell. The Great Friendship: Soviet Historians on the Non-Russian Nationalities. Chapel Hill: University of North Carolina Press, I965.

Tolstov I 947

Tolstov, S. P. “Osnovnye problem etnogeneza narodov srednei asii." Sovetskaia etnografiia 6-7 (I947), pp. 303-5. Ülvi 20I5 [I925]

Ülvi, Almaz. Alisher Nevai haqqinda iki maqala, 2015. Retrieved from http://kh-davron.uz/kutubxona/turk/ almaz-ulvi-\%C9\%gglisir-n\%C9\%9gvai.html. 